\title{
Birinci Dünya Savașı'ndaki Alman Propaganda Kartpostallarında Kullanılan Karikatürlerde Türklerin Sunumunun Göstergebilimsel Açıdan Incelenmesi
}

\author{
Caner Çakı ${ }^{1}$
}

\begin{abstract}
Öz
Birinci Dünya Savaşı'nda İttifak Devletleri Bloğu'nun başını çeken Alman İmparatorluğu, savaşta düşmanlarına korku salmak, müttefiklerini ise kendi bloğunda tutabilmek için propaganda kartpostallarını etkin bir şekilde kullanmıştır. Bu süreçte Almanya'da, özellikle Türkiye'yi (Osmanlı İmparatorluğu) konu alan pek çok propaganda kartpostalının ortaya çıktığı görülmüştür. Bu çalışmada, Birinci Dünya Savaşı’nda Almanya'da kullanılan propaganda kartpostallarındaki karikatürlerde, Almanların müttefiki Türkleri, nasıl ve ne şekilde sundukları incelenmeye çalışılmıştır. Bu açıdan amaçı örnekleme metodu kullanılarak belirlenen Türklerin konu edildiği beş Alman propaganda kartpostalı çalışmada analiz edilmiştir. Seçilen propaganda kartpostalları, Roland Barthes'ın düzanlam (dénotation), yananlam (connotation), metafor, metonim ve mit kavramları çerçevesinde yorumlanmıştır. Çalışmada elde edilen bulgular ışığında Almanların Birinci Dünya Savaşı'nda kartpostalları propaganda amaçlı kullandığı, Alman propaganda kartpostallarındaki karikatürlerde Türklerin "fes", "şalvar" ve "bayrak" metonimleri içerisinde sunulduğu ve Türklerin genel olarak "cesur", "kahraman" ve "güçlü" metaforları içerisinde açıklandığı ortaya çıkarılmıştır.
\end{abstract}

Anahtar Kelimeler: Propaganda, Kartpostal, Göstergebilim, Karikatür, Tarih

Atıf: Çakı, Caner. (2018) Birinci Dünya Savașị' ndaki Alman Propaganda Kartpostallarında Kullanılan Karikatürlerde Türklerin Sunumunun Göstergebilimsel Açıdan İncelenmesi. Akdeniz Üniversitesi Illetișim Fakültesi Dergisi, (AKIL) Haziran (29) s. 73-94 


\title{
The Semiotic Study of the Presentation of the Turks on the Caricatures Used in German Propaganda Postcards During the First World War
}

\begin{abstract}
In the First World War, the German Empire, which took the lead of the Central Powers, used propaganda postcards effectively to terrorize its enemies in the war and keep its allies on its own block. In this process, it was seen that in Germany, in particular, Turkey (Ottoman Empire) was the subject in many propaganda postcards. In this study, it was tried to examine how the Germans presented their allies -Turks- in the propaganda postcards used in Germany during the First World War. The caricatures used in German propaganda postcards which were selected using purposeful sampling method were analyzed by Roland Barthes' semiotic analysis technique. The selected propaganda postcards were interpreted in the context of Barthes' concepts: dénotation, connotation, metaphor, metonym, and myth. The findings of the study revealed that the Turks in German propaganda postcards were presented in the "fez", "salwar" and "flag" as metonym and that the Turks were generally described in metaphors such as "brave", "hero" and "strong" and the Germans used the caricatures of the postcards for propaganda purposes during the First World War.
\end{abstract}

Keywords: Propaganda, Postcards, Semiotics, Caricature, History 


\section{Giriș}

T ürk-Alman ilişkilerinin geçmişi 16. yüzyıla kadar gitmektedir. Buna karşın, iki toplum arasındaki dostluk bağlarının 19. yüzyıldan itibaren oluşmaya başladığı söylenebilir. 19. yüzyılın ikinci yarısından itibaren gerek Osmanlı Devleti'nin toprak bütünlüğünü korunmasında İngiltere ve Fransa'dan yeterli destek görememesi, gerekse Almanya'nın 1871 yılında birliğini sağlamasından sonra kendine yeni müttefik arayışına girmesi, iki ülkenin birbirine yakınlaşmasına zemin hazırlamıştır. 1878 Berlin Kongresi ile başlayan süreçte, Alman Başbakan Otto von Bismarck'ın Osmanlı Devleti'nin çıkarları doğrultusunda karar alması Türklerin Almanlara yönelik olumlu tutum sergilemelerini sağladı. İlerleyen süreçte Alman İmparatoru II. Wilhelm'in 1898'de Osmanlı Devleti'ndeki resmi ziyareti esnasında "300 milyon Müslüman'ın dostuyum" sözü, Almanya'nın Müslümanlar nezdinde sempati kazanmasının yanında, Türk Alman dostluğunun da pekişmesini sağladı (Salih, 2017: 500).

Birinci Dünya Savaşı'nda Almanya ve Osmanlı Devleti'nin aynı blokta yer alması iki devlet arasındaki ilişkilerin en olumlu döneminin yaşanmasına yol açtı. Bu dostluk, dönemin Alman gazete, dergi, poster ve kartpostallarındaki siyasi içerikli karikatürlerine de yansımıştır. Bu karikatürler Türk ve Alman ilişkilerinin daha da güçlenmesi için Alman İmparatorluğu tarafından propaganda amaçlı kullanılmıştır. Özellikle Almanya tarafından basılan kartpostallarda, Türk-Alman dostluğunu vurgulayan pek çok karikatüre yer verilmiştir. Bu karikatürlerde, Türklerin günlük hayatından, İtilaf Devletleri'ne karşı savaştığı cephelere kadar pek çok farklı konu işlenmiştir.

Alanda kapsamlı bir literatür taraması yapıldığında, göstergebilimsel analiz yöntemi kullanılarak propaganda afişlerinin ve resimlerinin incelendiği önemli çalışmalara rastlanılmaktadır. Örneğin, Özgişi (2013), "Bir Siyasi İmge Olarak Çocuk ve Savaşlar: I. Dünya Savaşı Örneği” adlı çalışmada çocukların propaganda kartpostallarında ne şekilde sunulduğunu, Işık ve Eşitti, (2015) "I. Dünya Savaşı Propaganda Afişlerinde Kadın Temsillerinin Toplumsal Cinsiyet Bağlamında Göstergebilimsel İncelenmesi" adlı çalışmada, kadınların Birinci Dünya Savaşı'ndaki propaganda afişlerinde hangi rol modeller içinde gösterildiğini ortaya koymaya çalışmıştır.

Akademik çalışmalar içerisinde Almanların gözünden Türk algısının incelendiği çalışmalara bakıldığında, Keleş’in (2016) "Birinci Dünya Savaşı Öncesi ve Sonrasında Almanlarda Türk İmgesi” adlı çalışmasında, Birinci Dünya Savaşı öncesi ve sonrasında Almanların Türklere yönelik bakış açılarını ayrıntılı bir literatür taraması ile ortaya koyduğu görülmektedir.

Filmlerdeki algıların göstergebilimsel analizi üzerine Çakı vd. (2017), "Türk Sinemasında Nazizm İdeolojisi: ‘Kırımlı' Filmi ve Göstergebilimsel Analizi” adlı çalışmaları örnek olarak gösterilebilir. Bu çalışmada, Roland Barthes'ın göstergebilimsel analiz yöntemi bağlamında Kırımlı filmi özelinde Nazizm ideolojisinin filmde nasıl ve ne şekilde sunulduğu incelenmiştir. Reklamlarda Roland Barthes'ın göstergebilimsel analizi üzerine ise Tanyeri Mazıcı ve Çakı (2018) "Adolf Hitler'in Korku Çekiciliği Bağlamında Kamu Spotu Reklamlarında Kullanımı" adlı çalışma örnek gösterilebilmektedir. Çalışmada, reklam afişleri Barthes'ın yananlam ve düzanlam kavramları üzerinden ele alınmıştır. 
Alanda propaganda amaçlı karikatürlerin kartpostallarda kullanımını inceleyen herhangi bir çalışmaya rastlanılamamıştır. Ayrıca, Roland Barthes'ın göstergebilimsel metodu içinde yer alan, yananlam ve mit kavramları üzerinden propaganda kartpostalları üzerine detaylı incelemelerin yapılmadığı gözlemlenmiştir. Nitekim, bu çalışmada yapılan göstergebilimsel çözümlemede, propaganda kartpostallarının içinde yer alan gizli mesajlar açıklanmaya çalışılırken, kartpostallar aracılığıyla Türk-Alman ilişkilerinde oluşturulmak istenen mitin de çözümlenmesi amaçlanmıştır. Böylece, çalışmada propaganda kartpostallarında kullanılan karikatürler ile metafor, metonim ve mit kavramları içerisinde, Alman toplumunun Birinci Dünya Savaşı'nda aynı cephede savaştığı Türk toplumunu nasıl algıladığı ve kartpostallarında nasıl yansıttığı ortaya konmaya çalışılmıştır. Çalışma alanda ilk olması bakımından özgün bir boyut kazanmaktadır.

\section{Birinci Dünya Savașı Döneminde Türk Alman Ilișkileri}

Osmanlı Devleti, 19. Yüzyılda Avrupa'daki topraklarının büyük bir kısmını kaybetmişti. Bu yüzyılda kaybettiği toprakların önemli bir kısmı da Rusya'nın denetimi altına girmişti. Bu süreçte, eski müttefiki İngiltere ve Fransa'dan yeterli destek alamadığına inanan Osmanlı Devleti, yönünü 1871 yılında yeni birliğini sağlamış olan Almanya'ya çevirdi. İlerleyen süreçte Osmanlı Devleti, Almanya ile imzaladığı askeri ve ekonomik anlaşmalar ile dostluğunu pekiştirdi (Strachan, 2004: 22). Nitekim, Almanya, Osmanlı Ordusu'nu eğitmek ve güçlendirmek için pek çok Türk subayını Almanya'ya askeri eğitim amacıyla kabul etti (Ortaylı, 2006: 101). Bunun yanında Almanya, Osmanlı Devleti'ne dönem dönem Helmuth Karl Bernhard von Moltke, Colmar von der Goltz gibi önemli askeri stratejisti Osmanlı Ordusu'nu güçlendirmek amacıyla gönderdi (Beşikçi, 2012: 103).

1877-1878 Osmanlı-Rus Savaşı'ndan sonra Osmanlı Devleti, Rusya ile çok ağır şartlar altında Ayastefanos Antlaşması'nı imzaladı. Avrupa devletlerinin müdahalesi sonucu bu antlaşma yürürlüğe konmadan iptal edildi. İptal edilen bu antlaşmanın yerine dönemin Alman Başbakanı Otto von Bismarck'ın başkanlık ettiği Berlin Antlaşması imzalandı. $\mathrm{Bu}$ antlaşmada önceki antlaşmaya göre az da olsa Osmanlı Devleti lehine kararların alınması, Türk- Alman ilişkilerinin olumlu yönde seyretmesini sağladı (Beydilli, 1979: 481).

İlerleyen süreçte Alman İmparatorluğu'nun başına geçen II. Wilhelm, Türk-Alman Dostluğu'nun gelişmesi için büyük çaba harcadı. Nitekim, Alman kayzeri, 1888'de tahta çıktıktan sonra ilk resmi yurtdışı ziyaretini dönemin Osmanlı Padişahı II. Abdülhamit'e gerçekleştirdi. İlerleyen süreçlerde de $(1898,1917)$ Alman İmparatoru Osmanlı Devleti'ne ziyaretlerini sürdürdü. Bu ziyaretler, iki ülke arasında beliren dostluğun daha da pekişmesine katkı sağlarken, ekonomik, siyasi ve askeri yardımlaşmanın da önünü açtı (Atar, 2015: 72).

20. Yüzyıla gelindiğinde ise Osmanlı Devleti üzerindeki Alman nüfuzunun gittikçe hissedilmeye başlandığı görüldü. Nitekim, Almanya, Osmanlı Devleti topraklarında sürekli olarak yatırımlarını artırdı. Özellikle, o dönemde Almanlar tarafından finanse edilen Bağdat Demiryolu, Türk-Alman Dostluğu'nun en somut örneği olarak belirdi (Mulligan, 2017: 201). 
İttihat ve Terakki Cemiyeti'nin 1913 yılında Osmanlı Devleti'nin yönetimini tamamen ele geçirmesi, Türk-Alman Dostluğu'nun altın çağının da başlangıcı oldu. Özellikle cemiyetin en önde gelen isimlerinden biri olan Enver Paşa, Almanya ile Osmanlı Devleti'nin İngiliz, Fransız ve Ruslara karşı aynı cephede savaşa girmesini destekledi (Kent, 2005: 120). Buna karşın, İttihat ve Terakki Cemiyeti'nin Alman yanlısı tutumu, Türk ve Alman toplumunu bir araya getirirken, Rusya gibi büyük Avrupa devletlerinin Osmanlı Devleti aleyhine bloklaşmalarına zemin hazırladı (McMeekin, 2011: 11).

Almanya, 1 Ağustos 1914 yılında Rusya'ya savaş ilan ederek resmi olarak Birinci Dünya Savaşı'na katılmış oldu (Wilke, 2007: 16). Savaşın başlarında Almanlar, Tannenberg gibi önemli savaşlarda İtilaf Devletleri'ne karşı üstünlüğü elde ederek önemli zaferler kazandı (Chickering, 2002: 39). Diğer yandan Almanya Batı cephesinde, İngiliz ve Fransızlara karşı Schlieffen Planı adı verilen büyük bir harekata geçti (Mommsen, 1993: 31).

Birinci Dünya Savaşı başladığında Osmanlı Devleti her şeye rağmen İngiltere ve Fransa'nın yanında savaşta girmeyi denedi. Fakat İtilaf Devletleri'nden olumlu bir yanıt alamadı. Bununla birlikte Osmanlı Devleti'nin İngiltere'ye sipariş ettiği gemilerin, Ingiltere tarafından seferberlik nedeniyle Türklere verilemeyerek el konulması ilişkilerin daha da gerilmesine yol açtı. Kısa bir süre sonra Almanların iki savaş gemisini Osmanlı Devleti'ne vermesi ilişkilerin Almanya lehine şekillenmesine yol açtı. Diğer yandan, bazı Osmanlı devlet adamları, Rusya'nın Osmanlı Devleti'ne yönelik oluşturduğu tehlikede Almanya'nın önleyici bir güç olacağını düşünmekteydi (Alkan, 2014: 171).

Türkleri, Birinci Dünya Savaşı'nda Almanlara yaklaştıran bir diğer önemli neden de iktidarda bulunan Ittihat ve Terakki Cemiyeti'nin Turancı düşünceleriydi. Cemiyetin ileri gelenleri ve iktidarda büyük bir nüfuza sahip kişiler, Enver Paşa'nın etrafında birleşerek, Almanların desteğiyle Turancı ideolojinin gerçekleşebileceğine inanmaktaydı (Howard, 2003: 52).

Bunun yanında Almanya da, Osmanlı Devleti'ni Birinci Dünya Savaşı'nda yanında görmek istiyordu. Nitekim, Alman İmparatoru II. Wilhelm, Osmanlı Ordusu'nun iyi eğitilip ve silahlandırıldığında İtilaf Devletleri'ne karşı önemli bir güç haline gelebileceğine inanıyordu. Bunun yanında Almanya, Osmanlı Devleti'nin elinde bulundurduğu Müslümanların dini liderliği olan halifelik makamını da İngiliz ve Fransızlara karşı kullanmak arzusundaydı. Böylece, İngilizce Fransız idaresindeki Müslümanların ayaklanmasını sağlanabilecekti. Diğer yandan, Almanlar, İngilizlerin ellerinde tuttukları Süveyş Kanalı'nın Osmanlı Devleti tarafından ele geçirilmesi, İngilizlerin savaştan daha erken çıkmasına neden olabileceğine inanmaktaydı. Son olarak Osmanlı Devleti'nin savaşa girmesiyle savaştaki cephelerin sayısının artması, Alman İmparatorluğu'nun Avrupa'daki cephelerinin ağırlığını da hafifletmiş olacaktı (Mühlman, 2009: 71-76).

Osmanlı Devleti'nin Almanların yanında savaşa girmesi oldukça ani oldu. 1914 yılında iki Alman gemisi Goeben ve Breslau İngiliz donanmasından sıyrılarak, Çanakkale Boğazı'na geldi. İngilizler, gemilerin kendilerine teslim edilmesini istedi. Buna karşın Osmanlı Devleti iki gemiyi satın aldığını ve isimlerini "Yavuz" ve "Midilli" olarak değiştirdiğini ilan etti. Gemilerdeki mürettebata Osmanlı üniforması giydirildi ve gemilere Osmanlı flaması çekildi. İki gemi kısa süre sonra Rusların Karadeniz'deki limanlarını bombaladı. Böylece Osmanlı Devleti, Almanya'nın yanında savaş girmiş oldu (Aksakal, 2011: 196). 
Almanya ve Osmanlı Devleti Birinci Dünya Savaşı'nda birbirlerine destek verdiler. Örneğin, Almanya, Çanakkale Savaşları'nda Osmanlı Devleti'ne önemli desteklerde bulundu. Alman General Liman von Sanders, Çanakkale Cephesi'nde Osmanlı Orduları'nın önemli bir kısmının yönetimini üstlendi (Von Sanders, 2006: 97). Diğer yandan, eski Alman Genel Kurmay Başkanı Erich von Falkenhayn, Suriye ve Irak hattında İngilizlere karșı oluşturulan Osmanlı Devleti'nin Yıldırım Orduları Grup Komutanlığı'na getirildi (Guhr, 2007: 124). Almanya ayrıca Birinci Dünya Savaşı'nda Osmanlı Devleti'ne askeri mühimmat yardımlarında da bulunmuştur. Nitekim, Almanya'nın Osmanlı Devleti'ne gönderdiği mühimmatlar, Osmanlı Devleti'nin savaştan çıkmasından sonra da elinde kalmış, hatta Kurtuluş Savaşı'nda bile bu mühimmatların bir kısmı kullanılmıştır (Tutsak, 2014: 231).

Osmanlı Devleti ve Almanya arasında zamanla şekillenen dostluk, Birinci Dünya Savaşı'nda en üst düzeye çıktı. Bu süreçte iki ülke ekonomiden, askeriyeye pek çok alanda iliş̧ilerini güçlendirdi. Bu çalışmada, Birinci Dünya Savaşı'nda Almanya'da kullanılan propaganda kartpostallarındaki karikatürlerde Türk ve Alman dostluğunun nasıl yansıtıldığı ortaya konmaya çalışılacaktır.

\section{Propaganda Kavramı}

Propaganda sözcüğünün kökenine bakıldığında kelimenin, Latincedeki "propagare" kelimesinden geldiği görülmektedir. Kelime anlamı da "bir düşünceyi veya bir eylemi yaymak" olarak kullanılmaktadır (Öymen, 2014: 111). Propagandada bireylerden çok kitleler hedeflenmektedir. Hedeflenen kitleler de etki altında bırakılarak istenilen yönde ikna edilmeye çalışılmaktadır. Propaganda iletişim yönlü bir ikna çabasıdır. Diğer bir deyişle, propaganda fikirlerin, değerlerin bir kişiden veya bir gruptan, bir kişiye veya gruba ulaşımıdır (Taylor, 1998: 7). Propaganda tamamen bilinçli olarak kurgulanan ve karşı tarafın her ne pahasına olursa olsun iknası üzerine odaklanmaktadır (Akarcalı, 2003: 12).

Propaganda, eğitimden sanata toplum içinde pek çok alanda kullanılabilmektedir (Davies, 1997: 4). Propagandanın temel amacı hedef kitlenin belirli bir ideolojik veya toplumsal algı üzerinde ikna edilmesi ve istenilen yöne çekilmesidir (Çetin, 2014: 243). Propaganda disiplini kendi içinde, kendi doğrusunu ortaya koyan bir ikna sanatıdır. Propagandanın kendine ait yasaları mevcuttur, kitlelere istenilen ideoloji aşılandığında propaganda zaferini ilan eder (Domenach, 2003: 41).

Propaganda, genel olarak halkın çıkarına olduğu iddia edilerek önemli sembollerin manipüle edilmesiyle tutumların yönetilmesidir (Lasswell, 1927: 627). Bu süreçte propaganda kendi içinde bazı temel birimlere ayrılmaktadır. Bu temel birimler ise üç ana başlık altında incelenmektedir; beyaz propaganda, gri propaganda, kara propaganda (Tarhan, 2010: 36).

Beyaz propagandada, propagandayı yapan tarafın kaynağı bellidir. Tüm bilgiyi doğrudan, açık bir şekilde ifade eder. Asla kitleleri manipüle etme yoluna gitmez. Anlatılması gerekenlerin hem olumlu hem de olumsuz yönlerini söyler. Mutlak suretle doğruluk üzerine hareket eder. Kitleler üzerinde güven oluşturmayı amaçlar (Tarhan, 2010: 37). 
Gri Propaganda, kaynağı tam olarak ortaya çıkmadığı durumlarda belirir. Doğruluğu her zaman kanıtlanması mümkün değildir. Gri propagandada "söylentiler" ve "iddialar" kitlelerin manipüle edilmesinde önemli rol oynar. Bilgiyi olduğu gibi vermekten çekinir. Olumlu yönleri üzerinden kitleleri ikna etmeye çalışırken, olumsuz yönlerini açıklamaz, hatta kimi zaman saklar (Tarhan, 2010: 38).

Kara propagandada, propaganda yapan kişi veya grubun kaynağı bellidir. Buna karşın, bilgi başka yerden ortaya atılmış gibi aksettirilir. Kara propaganda da temel amaç kitleleri ikna etmek ve onları istenilen yöne çekmektir. Bu yolda yalan, iftira ve hile doğal kabul edilir. Olmamış durumları gerçekmiş gibi kitlelere sunar (Tarhan, 2010: 41). Propaganda kelimesinin günümüzde olumsuz olarak algılanmasının en önemli nedenlerinden biri, propagandanın kitleleri manipüle etmek amaçlı "kara propaganda" şeklinde kullanılmasıdır. Nazi Almanyası iktidara geldiğinde ve sonrasında propagandayı etkin bir şekilde kullanmıştır (Welch, 2002: 5). Nitekim, özellikle 2. Dünya Savaşı'nda Nazilerin kurdukları Halkı Aydınlatma ve Propaganda Bakanlığı'nın başındaki Dr. Joseph Goebbels'in, propagandayı bir yalan söyleme sanatı haline getirmesi, milyonların gözünde propaganda kavramının, yalan söylemekle eş değer kabul edilmesine yok açmıştır (Fawcett, 2011: 173).

Propaganda, 19. ve 20. Yüzyılda kitle iletişim araçlarında yaşanan gelişmelerin ardından yaygın bir kullanım olanağı buldu. Nitekim, gazete, radyo ve sinema gibi kitle iletişim araçlarının kullanımının hızla yangınlaşması, propagandanın da kullanımını ve etkisini de doğru orantılı olarak arttırdı (Jowett ve O'donnell, 2014: 105).

Birinci Dünya Savaşı sürecinde propaganda tamamen profesyonel ellerde şekillenmeye başladı. Ülkeler, propagandayı sistematik bir hale getirerek, çıkarlarını propaganda faaliyetleriyle korumayı denedi (Dupré, 2013: 137). Bu savaşta ilk defa ülkeler ulusal boyutta olduğu kadar, uluslararası boyutta da kamuoyunu denetim altına almaya çalıştı. Özellikle kitle iletişim alanında yaşanan büyük değişimler propaganda faaliyetlerinin geniş kitlelere ulaşmasının önünü açtı (Qualter, 1980: 258).

2. Dünya Savaşı'nda propaganda kavramının altın çağını yaşadığı söylenebilmektedir. Bu süreçte Nazi Almanyası, Faşist İtalya ve Komünist Rusya'da tek partinin egemen olması ve kitle iletişim araçlarının denetiminin tek elde toplanması, propaganda disiplininin tek yönlü iletişim yapısının bu ülkelerde hakim olmasına yol açtı (Atabek, 2003: 7). Diğer yandan Birinci Dünya Savaşı'ndan sonra gelişen modern kitlesel propaganda faaliyetleri radyo ve sinemanın yaygınlık kazanmasıyla kitleler üzerinde daha etkili hale gelmiştir.

\section{Birinci Dünya Savașı'nda Almanya Kartpostallarında Bulunan Karikatürlerin Propaganda Amaçı Kullanımı}

Karikatür, genel olarak bir kişinin abartı öğesi kullanılarak resim veya çizim yoluyla tasvir edilmesini ifade etmektedir. Karikatürlerin geçmişi insanlık tarihi kadar eski olsa da, popülerlik kazandığı dönem 19.yüzyıla rastlar. Karikatürler 19.yüzyılda demokratik yönetimlerde, eleştiri amaçlı yazılı basında yer almaya başladı. Eleştirmenler, herhangi bir konuda yazı kaleme aldıklarında, muhaliflerine karşı karikatürlerden yararlanmaktaydılar. Nitekim, karikatürler bir kişinin belli özelliklerinin abartılması neticesinde karşı tarafa mesaj aktarımında, resim ve fotoğrafların çok ötesinde bir 
etkiye sahiptir (De Villalba, 2013: 76). Fotoğrafların gazete ve dergileri yeni yeni süslemeye başladığı 19.yüzyılda, karikatürler -fotoğraflara göre- gerek ucuz maliyeti, gerekse verilmek istenen mesajları etkili bir şekilde aktarmasından dolayı yazılı basında çok daha revaçta idi.

Diğer yandan karikatürler siyasi ve sosyal konuların bir çizim ile özetlenmesini sağlamaktadır. Kimi zaman sıradan bir karikatür, onlarca sayfa yazının yerine geçebilmektedir (Rudwick, 1975: 534). İnsanların belli bir konuda dikkatini çekmek isteyen yazarlar, bazen manşetlerini bir karikatür ile süslemekte ve hiç bir yazıya intiyaç duymadan anlatmak istediklerini ortaya koyabilmektedir.

20.yüzyıla gelindiğinde karikatürler etkili bir propaganda aracı olarak kullanılmaya başlandı. Özellikle, Birinci Dünya Savaşı'nda kitap, gazete, dergi, afiş ve kartpostallarda karikatürler propaganda aracı olarak hem İtilaf Devletleri, hem de İttifak Devletleri tarafından yoğun olarak kullanıldı (Demm, 1993: 163; Messinger, 1992: 16). Propagandanın o güne değin hiç olmadığı kadar yoğun olarak kullandığı Birinci Dünya Savaşı ’nda (Schwendinger, 2010: 8) karikatürler düşman ülkelerin birbirlerini hicvettikleri birer propaganda silahı haline dönüştü. Nitekim, bu dönemde propaganda ile birlikte karikatürler de altın çağını yaşamaya başladı.

Savaşta karikatürler yoluyla ulusal ve uluslararası boyutta kamuoyunun etkilenmesi için çaba sarf edilmiştir. Fotoğraflardan ziyade propaganda faaliyetlerinde karikatürlerin kullanılmasındaki en önemli nedenlerden biri karikatürler aracılığıyla abartı unsurunun kullanılabilmesidir. Karikatürlerde kötülenmek istenen tarafın olumsuz yönleri olanın ötesinde abartılı olarak gösterilebilmektedir (Harris, 1993: 184). Karikatürlerde kullanılan abartı unsuru kitlelerin korku, hayranlık, nefret gibi pek çok farklı duygusunun harekete geçmesine de yol açabilmektedir.

Karikatür içeren kartpostallar propaganda faaliyetleri yürütenler için önemli bir araçtır. Nitekim, kolay ulaşılabilen ve ucuz bir iletişim aracıdır. Bunun yanında ressam veya karikatürist kartpostaldaki karikatürü istediği şekilde resmedebilmektedir. Burada tamamen çizenin etkin olduğu görülür (Fraser, 1980: 40). Örneğin, Birinci Dünya Savaşı'nda Alman propaganda kartpostalları incelendiğinde Alman, AvusturyaMacaristanlı, Türk ve Bulgar askerlerinin fiziksel olarak kuvvetli ve korkusuz görüntüsünün ardında, İngiliz, Fransız, Rus askerlerinin çelimsiz, zayıf ve korkak resmedildiği görülebilmektedir.

Kartpostalların kitleler üzerindeki etkisinin farkına varan Almanya, Birinci Dünya Savaşı esnasından propaganda amaçlı onlarca kartpostal piyasaya sürdü. Bu kartpostallarda yer alan karikatürlerde, Alman İmparatoru II. Wilhelm'in kahramanlığından, Alman askerlerinin cesaretine kadar pek çok farklı konuda propaganda öğesi Alman kartpostallarını süsledi (Diekmannshenke, 2006: 103). Diğer yandan, dönemin tüm kitle iletişim araçlarında olduğu gibi kartpostalların denetimi de Alman İmparatorluğu'nun elindeydi. Savaş döneminde Alman İmparatorluğu'nda uygulanan sansür, kartpostalların yönetimi eleştiren bir şekilde propaganda yapmasını engelledi (Brocks, 2008: 25). Diğer yandan, Alman propaganda kartpostallarında savaşın acımasız ve korkutucu yüzünün bir az olsun azaltılması için çoğu zaman sıradan asker resimlerinin yanında, kadın ve çocuk asker resimleri de kullanıldı (Hoffmann, 1997: 332). Diğer yandan kadın ve çocuk karikatürleri ile verilmek istenen mesajın mizahi bir anlam taşıması da sağlandı. 
Birinci Dünya Savaşı, kartpostalların propaganda amaçlı kullanımında altın çağ yaşamasına neden oldu. Cephedeki askerler, yakınlarına mektup yollamaktansa daha kısa sürede ve daha pratik yoldan kartpostal göndermeyi tercih etmekteydi (Fraser, 1980: 40). Savaşta, kartpostallar askerler tarafından cephenin arkasından haber alınmasını sağlayan bir nevi haber kaynağı görevi de görmekteydi. Almanya'da yaşanan önemli tüm gelişmeler kartpostalların gündemindeydi (Saunders, 2004: 168). Diğer yandan, kartpostallar, askerlerin cephe gerisinde aileleriyle iletişim kurmalarında önemli bir iletişim aracı haline geldi (Jaworski, 2015: 12).

Kartpostalların Birinci Dünya Savaşı Dönemi'nde yoğun olarak kullanılmasının altında yatan diğer önemli neden de, kartpostalların günümüzdeki e-maillerin görevini görmesiydi. İnsanlar verilmesi gereken kısa mesajları kartpostallar vasıtasıyla istedikleri yöne ulaştırabilmekteydi (Carlson, 2009: 215).

Görsel iletişim araçlarının gelişmediği bir dönemde kartpostal Birinci Dünya Savaşı döneminde insanların vazgeçilmez bir iletişim aracı haline geldi. Özellikle görüntünün yayılması konusunda kartpostallar oldukça başarılıydı. Nitekim, 1914-1918 yılları arasında üretilen milyonlarca kartpostalın önemli bir kısmı propaganda amaçlı siyasal mesaj içermekteydi (Elsig ve Erismann, 2014: 14). Bu siyasal mesajlar, kartpostalların üzerine yerleştirilen karikatürler ile oluşturulmaktaydı.

Birinci Dünya Savaşı'nda propaganda amaçlı kullanılan resimlerde, düşman ülkeye karşı nefretin körüklenmesi, müttefik ülkelere karşı da dostluğun arttırılması amaçlanmaktaydı (Rother ve Breymayer, 1995: 94). Alman kartpostallarında İngiliz ve Fransız askerleri korkak ve gülünç, Alman askerleri ise korkusuz ve cesur olarak yansıtılmaktaydı.

Alman propaganda kartpostallarında Alman kamuoyunu savaşa devam etmeye, imparatora ve vatana sadakate, muhalif söylemlere itibar etmemelerine yönelik çalışma yürütülmekteydi. Nitekim, propaganda kartpostallarında resmedilen insanlara bakıldığında ülkesi için tüm gücüyle çalışan bir işçi ve toprağını tüm gayretiyle süren bir çiftçi görülmekteydi. Çalışan herkesin söylemi ise «Almanya için savaşıyoruz» idi. Kartpostallarda, her ne olursa Alman halkının savaşa istekli olduğu mesajı verilmeye çalışılıyordu (Jebsen, 2015: 165-166). Karikatürler yoluyla bu olanın (veya olduğu iddia edilen durumun) abartılı olarak yansıtılmasını sağlamaktaydı. Alman işçi daha çalışkan, Alman asker daha kahraman gösterilebilmekteydi.

Kartpostallardaki resimler, egemen güçler tarafından kimi zaman siyasi meşruiyetlerini sağlamlaştırmak (Özen, 2008: 146), kimi zaman da gündem oluşturmak için (Krieg, 1939: 664) propaganda faaliyetlerinde kullanıldı. Diğer kitle iletişim araçlarından farklı olarak kartpostallar üzerindeki resimlerde sanatçının bakış açısı ve sanatsal farklılığı yansıtıldığında propagandanın etkisi de artabilmektedir. Sanatçı kartpostalda olanı daha büyük ve etkili veya daha küçük ve gösterişsiz hale getirebilmektedir (Weiss ve Stehle, 1988: 80). Diğer yandan savaş dönemlerinde kullanılan kartpostallarda savaş anında çekilemeyen bazı fotoğraf kareleri, kartpostalda ressamlar tarafından resmedilebilmekte, savaş hakkında kitlelere bilgi verilebilmektedir (Scholl, 1987: 346). Yine bu süreçte, karikatürlerdeki sunum kodlarında dost askerler kahramanlar, düşman askerler ise zorbalar olarak çizilebilmekteydi. 
Bu çalışmada Birinci Dünya Savaşı'nda Almanya'daki propaganda kartpostallarındaki karikatürler özelinde, Almanların propaganda faaliyetleri ele alınarak, savaşta müttefiki Türkiye'yi propaganda kartpostallarında hangi sunum kodları içerisinde yansıttıkları ele alınmıştır.

\section{Göstergebilimsel Analiz Metodu}

Göstergebilim, bir diğer tanımıyla semiyotik insanlar arasında iletişim kurmak amacıyla kullanılan her türlü meta, düşünce ve davranışın anlamlandırılması ve açıklanması üzerine duran bir öğreti olarak ifade edilmektedir (Rıfat, 2013: 99). Göstergebilim, 19. ve 20. yüzyılda, İsviçreli Ferdinand de Saussure ve Amerikalı Charles Sanders Peirce'ın yapmış olduğu çalışmalar sayesinde tüm dünyada bilinmeye başlandı. Bu iki dilbilimcinin ortaya attığı göstergelerin anlamlandırma ve yorumlanma biçimleri Fransız Dilbilimci Roland Barthes tarafından geliştirildi ve daha anlaşıır bir şekilde göstergebilimdeki dizgelerin yorumlanmasını sağladı.

Barthes, göstergelerin anlamlandırma sürecini iki düzlem üzerine konumlandırdı; düzanlam (dénotation) ve yananlam (connotation) (Kocabay, 2008:34). Göstergebilimin içinde yer alan düzanlam göstergelerin bireylerin zihinlerinde canlandırdığı ilk anlamı ifade etmektedir. Yananlam ise verilmek istenen mesajın sunum kodları içinde gizlenen ve ilk aşamada insanların aklında belirmeyen anlamını ifade etmektedir. Bu açıdan yananlam, düzanlamdan farklı bir boyuta sahiptir (Barthes, 2016: 86). Dizgenin içinde yer alan göstergelerin vermek istediği mesaj gösterilen boyutta değerlendirildiğinde yananlamda mevcuttur (Barthes, 1980: 4). Barthes'ın göstergebilim anlayışında yer alan göstergelerin yorumlanış biçimi yalnızca sözlerin oluşturduğu dizgelerden değil, kullanılan giysilerden, yenilen yemeklere kadar çok geniş bir alanı ifade etmektedir (Barthes, 2012: 112).

Yananlamda gösterge izleyicinin kültürel bilgisi içinde yorumlanarak ortaya çıkmaktadır. Yani, yananlam o dili kullanan topluluğun bireylerinin bilgi, deneyim ve düşünceleri içinde şekillenebilmektedir. Her gösterge mutlaka bir yananlam barındırmaktadır. Bu yananlam kültürden kültüre farklı şekilde yorumlanabilmektedir. Bu süreçte önemli olan belirli bir kültür içinde yer alan bireylerin, göstergeyi nasıl ve ne şekilde yorumladığıdır. Yananlam, kültüre özgüdür ve o kültürün içinde anlam kazanır (Sığırcı, 2016: 74). Bir düzlem içinde yananlam veya düzanlamın ağırlığını hissettirdiği gözlemlenebilmektedir. Eğer düzanlam bir dizgede yoğun olarak hissediliyorsa burada bilimsel bir ifadenin net olarak ortaya konulduğu gözlemlenebilmektedir. Çünkü düzanlamda net bir açıklama ve ifade vardır. Buna karşın sanatsal bir düzlemde ressam, heykeltıraş veya şair pek çok farklı mesajı ve algıyı eserinde sunabilmektedir. Bu da yananlamın çok anlamlılığını ifade eder (Guiraud, 2016 :46). Çalışma kapsamında incelenen karikatürler boyutunda ele alındığında, çizenin düşünce yapısı ve algıları doğrudan karikatürde verilmek istenen mesaja yansıyabilmektedir.

Barthes, göstergelerin yorumlanmasında mit, metafor ve metonim kavramlarının da üzerinde durur. Metonim, bir metanın, bir durumun veya bir kişinin temsil edilmesi için o şeye ait bir özelliğin sunulmasıdır (Geray, 2014: 168). Örneğin, bir propaganda kartpostalında Hitler'in resmi yerine onun var olduğunu ifade etmek için, Hitler'e has saç tarzı ve bıyık biçiminin kullanılması bir metonim olarak açıklanabilmektedir. 
Barthes'ın ortaya koyduğu mit kavramında, günlük hayatta yaşanan her şeyin ve her olgunun burjuva değerleri içinde bir anlam kazandığını söylemektedir. Mit iki temel işleve sahiptir. Dizgeler içerisinde anlamı hem gösterir hem de bildirir. Düzlemde yer alan herhangi bir resim, fotoğraf, şekil vb. mit içinde gerçek anlamın dışında farklı bir yoruma kavuşur (Ünal, 2016: 395-396). Örneğin, kadınların erkeklerden daha iyi yemek yaptığı, çocuklara daha iyi baktığı toplum tarafından kadınlara atfedilen bir mittir. Kadınlar bu konularda erkeklerden daha başarılı ise kadının yeri evi olmalıdır (Geray, 2014: 167). Mitlerin toplum içindeki anlamlarının tarihsel süreç içerisinde oluştuğu gözlemlenmektedir. Mitin anlamlandırması toplum tarafından zamanla kabul edilmekte ve ortak bir fikir oluşturmaktadır (Sepetçi, 2016: 494).

Bu çalışmada, Birinci Dünya Savaşı'nda Almanya'da kullanılan propaganda kartpostallarında yer alan karikatürlerde, Almanların müttefiki Türkleri, nasıl ve ne şekilde sundukları Roland Barthes'ın göstergebilime kazandırdığı yananlam, düzanlam ve mit kavramları temelinde incelenmeye çalışıımıştır. Çalışmada analiz edilen propaganda kartpostallarındaki karikatürler, Birinci Dünya Savaşı döneminde Almanların Türklere yönelik algılarının nasıl olduğu ve bu algıyı kartpostallara ne şekilde yansıttıklarını ortaya koymaktadır.

\section{Birinci Dünya Savașı'nda Türkleri Konu Alan Alman Propaganda Kartpostallarındaki Karikatürlerin Göstergebilimsel Açıdan İncelenmesi}

\section{1. Calıșmanın Yöntemi}

Çalışma kapsamında Birinci Dünya Savaşı'nda Almanya'da kullanılan ve Türkleri konu alan beş propaganda kartpostalı, nitel araştırma yöntemlerinden biri olan göstergebilimsel analiz metodu kullanılarak incelenmiştir. Kartpostallarda kullanılan kartpostallar, Fransız Dilbilimci Roland Barthes'ın yananlam, düzanlam ve mit kavramları üzerinden analiz edilmiştir.

\section{2. Çalıșmanın Amacı}

Birinci Dünya Savaşı döneminde Almanya'da kullanılan ve Türkleri konu alan propaganda kartpostalında Türklerin nasıl ve ne şekilde sunulduklarının ortaya konması çalışmanın temel amacını oluşturmaktadır. Diğer yandan, kartpostallardaki sunum kodları içerisinde Türklerin hangi metonim ve metaforlar içerisinde yer bulduğu da çalışma kapsamında açıklanmaya çalışılmıştır.

\section{3. Çalıșmanın Evreni ve Örneklemi}

Birinci Dünya Savaşı'ndaAlmanya'da kullanılan ve Türkleri konu alan Alman propaganda kartpostallarındaki karikatürlerin tümü çalışmanın evrenini oluşturmaktadır. Buna karşın tüm evrene ulaşmanın güçlüğünden dolayı, evreni en iyi yansıtacağı düşünülen beş propaganda kartpostalı amaçı örneklem metodu kullanılarak örneklem olarak belirlenmiştir.

Çalışma kapsamında Birinci Dünya Savaşı ’ndaki Alman kartpostallarındaki karikatürler incelendiğinde, karikatürler ekseriyetle Alman İmparatoru II. Wilhelm, Osmanlı İmparatoru VI Mehmet, Avusturya Macaristan Imparatoru Franz Joseph ve Bulgar Kralı 
I. Ferdinand'ın dördünün bir arada bulunduğu karikatürleri içermektedir (sikhmuseum, 2018). Bu kartpostallardaki karikatürlerde, daha çok liderlerin gücü ve otoritesine vurgu yapılmış, İttifak Devletleri'nin, İtilaf Devletleri'ne karşı bir arada olduklarının altı çizilmiştir. Bu karikatürlerde, dört devletin eşit bir şekilde ortak düşmana karşı savaştığı vurgulanmaktadır. Çalışmaya dahil edilen 5 karikatürde ise daha çok kadın ve çocuklar kullanılarak, Alman toplumuna Türk toplumu ile ilgili mesajların verilmeye çalışıldığı görülmektedir. Kadın ve çocukların karikatürlerde yer alması liderlerin fotoğrafları ile verilemeyen yananlam boyutundaki gizli mesajların verilmesi sağlamıştır. Diğer yandan Türk toplumunu temsilen kullanılan kadın ve çocuk karikatürleri ile abartı ve mizah öğelerinin kullanılmasının da önü açılmıştır. Bu açıdan, İttifak Devletleriınin liderlerinin bulunduğu karikatürler çalışmanın dışında bırakılmıştır (Resim 1).

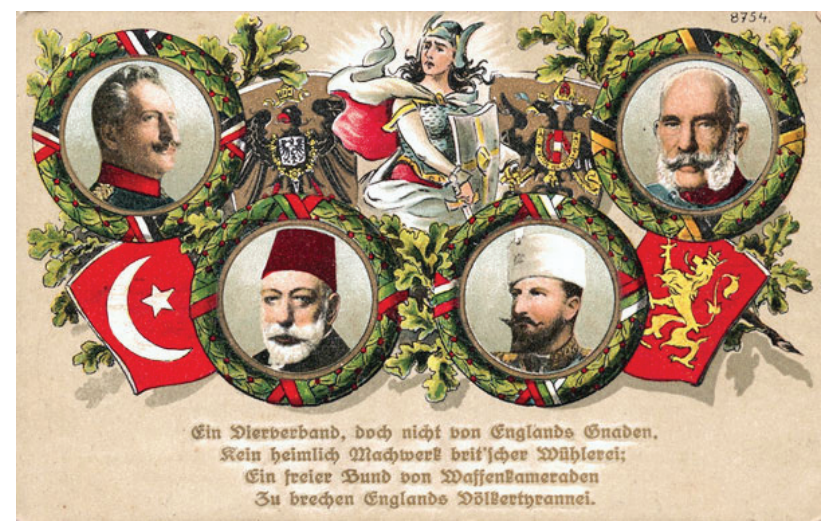

Resim 1: İttifak Devletleri'nin Liderleri

\section{4. Çalıșmanın Sınırlılıkları}

Birinci Dünya Savaşı döneminde Almanya'da Türkleri konu alan pek çok propaganda kartpostalının kullanıldığı bilinmektedir. Çalışma kapsamında bu propaganda kartpostalları içerisinden yalnızca beş kartpostalın örneklem olarak seçilmesi çalışmanın temel sınırlılığını oluşturmaktadır. Diğer yandan, göstergebilimsel analiz yöntemi kullanılırken yalnızca Fransız Dilbilimci Roland Barthes'ın analiz metodunun kullanılması çalışmanın diğer önemli sınırııı̆ını meydana getirmektedir.

\section{5. Çalıșmanın Önemi}

Çalışmanın alanda özgün olması, gelecek çalışmalar için kaynak teşkil etmesi açısından önem taşımaktadır. Bunun yanında çalışma,

-İncelenen propaganda kartpostallarındaki karikatürlerin Birinci Dünya Savaşı döneminde Almanların Türklere yönelik algılarını göstermesi,

-Türklerin, kartpostallardaki karikatürlerde hangi sunum kodları içerisinde yansıtıldığını ortaya koyması,

-Almanya'nın savaş döneminde müttefiklerini yanında tutabilmek için propaganda kartpostallarından nasıl ve ne şekilde yararlandığını açıklaması bakımında da önem taşımaktadır. 


\section{6. Calıșmanın Soruları}

Çalışma kapsamında aşağıdaki soruların ortaya çıktığı görülmektedir;

- Birinci Dünya Savaşı'nda Türkleri konu alan Alman propaganda kartpostallarındaki karikatürler de Almanlar Türkleri nasıl ve ne şekilde konu etmiştir?

-Birinci Dünya Savaşı'nda Türkleri konu alan Alman propaganda kartpostallarındaki karikatürlerde Türkler hangi sunum kodları içerisinde sunulmuştur?

- Birinci Dünya Savaşı'nda Türkleri konu alan Alman propaganda kartpostallarındaki karikatürlerde Türkler hangi metafor, metonim ve mit kavramları içerisinde sunulmuştur?

\subsection{Verilerin Çözümlenmesi}

Çalışmanın bu bölümünde amaçlı örneklem metoduna göre seçilen beş Alman propaganda kartpostalı (Türk Misafirperverliği, El Ele Tutuşan Çocuklar, Kadın Askerler, Doğunun Uyanışı, Birlik Güçlü Yapar) Roland Barthes'ın düzanlam, yananlam ve mit kavramları temelinde analiz edilecektir.

\subsection{1. "Türk Misafirperverliği” Kartpostalı}

Türk misafirperverliği adındaki kartpostal Barthes'ın düzanlam boyutunda değerlendirildiğinde, kartpostalda bir Alman askeri, bir Avusturya-Macaristan askeri, yaşlı bir Türk adam ve yüzü gösterilmeyen arkasına dönmüş halde bulunan bir köylü kadın yer almaktadır. Bulundukları yer bir Türk köyüdür. Kartpostal, "Türk Misafirperverliği” adıyla basılmıştır (Resim 2) (Dortmund-postkolonial, 2017a).

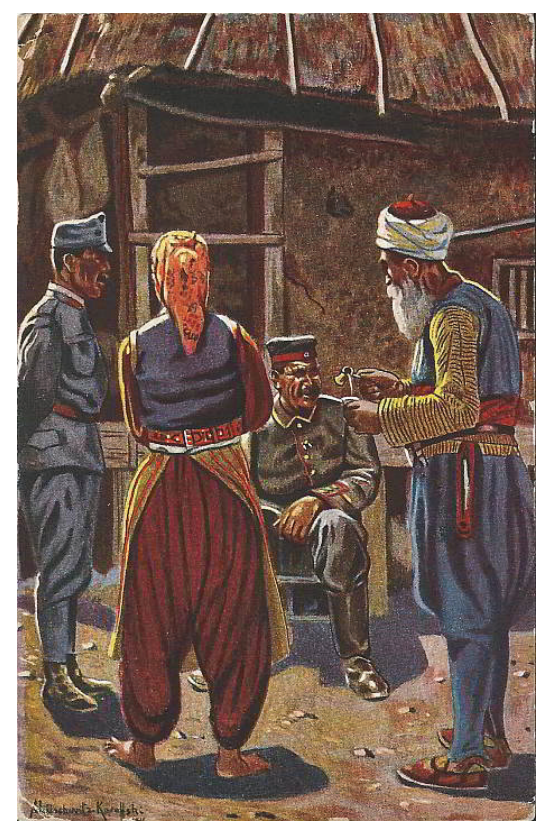

Resim 2: "Türk Misafirperverliği” Kartpostalı 
Kartpostalda, Alman askeri ve Avusturya-Macaristan askerinin, askeri üniforma metonimleri kullanılarak hangi milletlere ait oldukları gösterilmiştir. Yine kartpostalda yer alan köylü adam ve kadının giydikleri yerel kıyafetler birer metonim olarak bu iki kişinin Türk olduğunu yansıtmaktadır. Kartpostalda bir Alman ve bir Avusturya-Macaristan askerinin bir Türk köyüne misafir olması konu edilmiştir. Nitekim, kartpostalda yer alan "Türk misafirperverliği" başlığı bu durumu güçlendirmiştir. Alman askeri oturmuş, yaşıı Türk erkeği cezve içinde Alman ve Avusturya-Macaristan askerine kahve ikram etmektedir.

Barthes'ın göstergebilim anlayışı içinde değerlendirildiğinde, Türk halkının misafirperver bir yapıda olduğu, kapısına gelen misafirlere ikramda bulunduğu miti oluşturulmaya çalışılmıştır. Nitekim, Türk köylüsü bu kartpostalda «misafirperver», «dost» ve «cömert» metaforları içerisinde Alman propaganda kartpostallarında sunulmuştur. Genel manada değerlendirildiğinde bu kartpostalda Türk ve Alman dostluğunun tesis edilmeye çalışıldığı sonucu elde edilebilmektedir. Tüm bu olumlu sonuçlara karşın kartpostalda yer alan sunum kodlarının olumsuz bir algıda değerlendirilmesi de mümkündür. Nitekim, yaşlı Türkün ayakta durması ve oturan askere kahve vermesi, Türklerin Almanlara "hizmet" ettiği yönünde bir mitin oluşmasına da zemin hazırlayabilmektedir.

\subsection{2. “El Ele Tutușan Çocuklar” Kartpostalı}

Bu kartpostalda, el ele tutuşmuş üç küçük çocuk bulunmaktadır. Çocuklardan ikisi asker selamı verirken, diğerlerine göre küçük olan çocuk iki büyük çocuğun elini tutmuştur. Büyük çocuklar askeri üniforma giyerken, küçük olanı ise okul üniformasına benzer bir kıyafet giymiştir. Büyük olan çocukların birinde kılıç, birinde tüfek, küçük olan çocukta ise bir kama bulunmaktadır. Küçük çocuğun diğer çocuklardan farklı olarak sırtında bir bayrak taşıdığı gözlemlenmektedir. Son olarak üç çocuk resminin altında Almanca "Ich sei, gewährt mir die Bitte, in eurem Bunde der Dritte! (Yalnız bir dileğim var, esirgemeyin benden, aranızda üçüncü biri olayım!) yazısı bulunmaktadır (Resim 3) (Dortmund-postkolonial, 2017b).

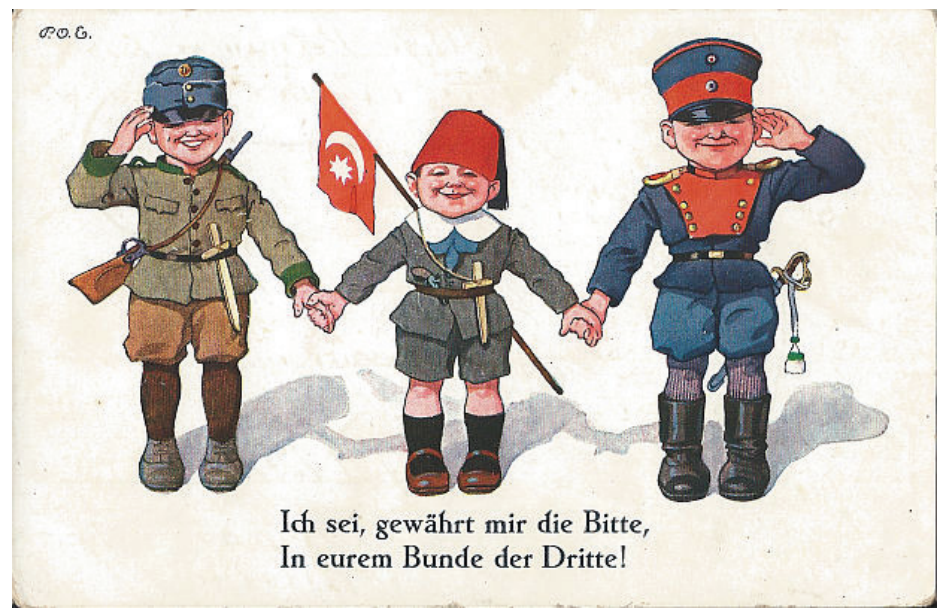

Resim 3: "El Ele Tutuşan Çocuklar" Kartpostalı 
Kartpostalda sol başta bulunan çocuğun Avusturya-Macaristan asker üniforması metonimiyle Avusturya-Macaristanlı, ortada yer alan küçük çocuğun fes ve bayrak metonimiyle Türk ve sağ tarafta bulunan çocuğun ise Alman üniforması metonimiyle Alman olduğu vurgulanmıștır. Barthes'ın yananlam boyutunda değerlendirildiğinde, Türk çocuğa atfedilen "Yalnız bir dileğim var, esirgemeyin benden, aranızda üçüncü biri olayım!" yazısı Osmanlı Devleti'nin Almanya ve Avusturya-Macaristan İmparatorluğu'nun yanında savaşa katıldığını ve Türklerin, Almanya ve AvusturyaMacaristan'ın dostluğunu ve müttefikliğini istediğini göstermektedir. Yazının yalnızca Almanca olması propagandanın Almanya ve Avusturya-Macaristan'da yaşayan Almanlara yönelik yapıldığını göstermektedir.

Barthes'ın yananlam boyutunda değerlendirildiğinde, Osmanlı İmparatorluğu'nun metonimi olarak kullanılan ve diğerlerine göre daha küçük gösterilen çocuğun, Alman ve Avusturya-Macaristanlı çocuklardan daha güçsüz olduğu, onlardan yardım istediği ve onların korumasına yöneldiği anlatılmak istenmiştir. Bu süreçte, Türklerin, Alman ve Avusturya-Macaristanlılardan daha güçsüz olduğu ve onlar ile müttefik olmak istediği miti oluşturulmaya çalışıldığı görülmektedir. Türkler kartpostaldaki karikatürde, "dost", "müttefik" ve "desteğe intiyaç duyan" metaforları içerisinde vurgulanmaktadır. $\mathrm{Bu}$ açıdan kartpostalda yer alan karikatürün olumlu ve olumsuz kodlar içinde iki farklı şekilde algılanması mümkündür. Kartpostaldaki sunum kodları olumsuz yönde değerlendirildiğinde, Türk çocuğun küçük olması, Türklerin, Almanya ve AvusturyaMacaristan İmparatorluğu'nun yardımı olmadan ayakta kalamayacağı şeklinde yorumlanmasına neden olabilmektedir. Olumlu sunum kodları içindedeğerlendirildiğinde ise Almanya ve Avusturya-Macaristan'ı temsil eden çocukların büyük gösterilmesi, Türklere yönelik koruyuculuk rolünün üstelenildiğini göstermektedir. Diğer yandan Osmanlı Devleti'nin Birinci Dünya Savaşı'nın başında İtilaf Bloğu'na geçme çabası ve sonrasında bu çabanın başarısız kalmasıyla İttifak Bloğu'na geçmesi de karikatürde verilmek istenen mesajlardan biri olabilmektedir.

\subsection{3. “Kadın Askerler” Kartpostalı}

Bu kartpostalda, Barthes'ın düzanlam boyutunda askeri üniforma giymiş dört kadın olduğu görülmektedir. Kadınlardan biri Türk,birisi Avusturya-Macaristan, birisi Alman, birisi ise Bulgar asker üniforması giymektedir. Her kadın askerin resminin üstünde onları temsil eden ülkelerin bayrakları yer almaktadır. Diğer yandan dört kadının da resimlerinin altında Almanca "Wir machen mit/ Katılıyoruz" yazısı yer almaktadır. Kadın askerlerin dördü de gülümseyerek bakmaktadır (Resim 4) (Dortmund-postkolonial, 2017c).

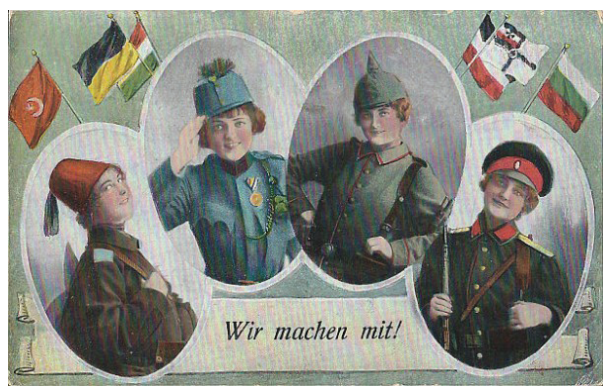

Resim 4: "Kadın Askerler" Kartpostalı 
$\mathrm{Bu}$ kartpostalda da, Osmanlı, Almanya, Avusturya-Macaristan ve Bulgaristan devletlerini anlatırken metonim olarak asker üniformalarının ve devlet bayraklarının kullandığı gözlemlenmektedir. Sunum kodları içerisinde kadınların kendilerine güvenen bakışları savaştaki kararlılığı göstermektedir. Diğer yandan Barthes'ın yananlam boyutunda analiz edildiğinde ise dört kadının, dört İttifak Devleti'ni temsilen Birinci Dünya Savaşı'ndaki müttefikliği, dostluğu, birliği ve güç merkezini yansıttıkları gözlemlenmiştir. Kartpostalda oluşturulmaya çalışılan mit, dört ittifak devletinin birlik içinde olduğu ve Birinci Dünya Savaşı'nı kararlılık ile devam ettirdiğidir. Nitekim, kartpostalda yer alan "Katılıyoruz" yazısı bu miti destekler niteliktedir. Askerler, "kararlılı", "birliktelik" ve "müttefiklik" metaforları içinde sunulmuştur.

\subsection{4. “Doğu’nun Uyanıșı” Kartpostalı}

Barthes'ın düzanlam boyutunda kartpostalda devasa boyutta bir fesin içinden onlarca askerin çıktığı ve Türk bayrağı taşıyıp süngü çekerek bir yere hücum ettikleri görülmektedir. Kartpostalda fesin arkasında yer alan güneş yine fes kadar devasa boyutta bulunmaktadır. Kartpostalın en üstünde ise Almanca olarak "Orient's Erwachen/ Doğunun Uyanışı” yazısı bulunmaktadır (Resim 5) (Dortmund-postkolonial, 2017d).

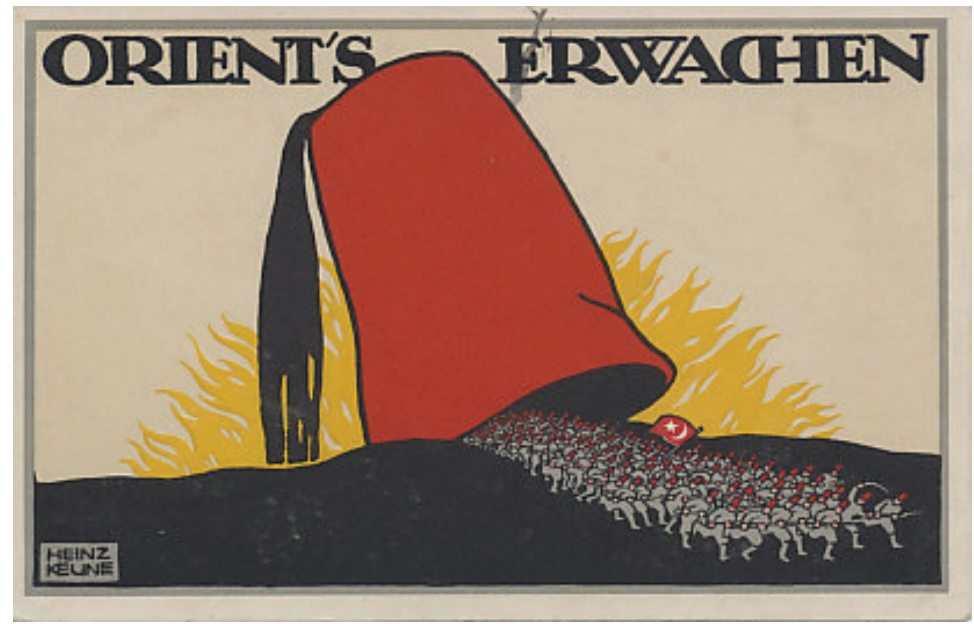

Resim 5: "Doğunun Uyanışı" Kartpostalı

Kartpostalda yer alan devasa büyüklükteki fes Osmanlı İmparatorluğu`nu temsil eden bir metonim olarak yer almıştır. Nitekim, kartpostalın üzerinde yazan «Doğu'nun Uyanışı" yazısındaki Doğu, Osmanlı İmparatorluğunu ifade etmektedir. Fesin altından saldırıya geçen askerlerin giydikleri fesler ve taşıdıkları Türk bayrağı bu askerlerin Türk olduğunu ifade eden metonimlerdir. Kartpostalda yer alan "uyanma" kelimesiyle verilmek istenen yananlam, kartpostaldaki bütün unsurlar içinde değerlendirildiğinde harekete geçme, Almanya ile birlik olma, İtilaf Devletleri'ne (İngiltere, Fransa, Rusya) saldırma anlamındadır. Diğer yandan "uyanma”, Osmanlı Devleti'nin İtilaf Devletleri'ne yönelik savaş ilanını anlatan bir metafor olarak değerlendirilmişsir.

İncelenen bu kartpostalda, Türklerin uzun zamandır sessiz kaldığı ve artık harekete 
geçerek bu sessizliği bozacağı miti oluşturulmaya çalışıımıştır. Alman propaganda kartpostalındaki sunum kodlarında, Türkler "kahraman", "zafer vaad eden" ve "muzaffer asker" metaforları içerisinde yer almıştır. Genel manada bu kartpostalda Türk halkı yüceltilerek, Türk halkının önemli bir müttefik olarak algılanması sağlanmıştır.

\subsection{5. “Birlik Güclü Yapar” Kartpostalı}

"Birlik Güçlü Yapar” kartpostalında düzanlam boyutunda, üç küçük çocuğun ellerindeki bayrakları birleştirip yukarı doğru kaldırdıkları görülmektedir. Çocukların üçü de askeri üniforma giymektedir. Kartpostalın hemen altında ise "Einigkeit macht stark P"Birlik Güçlü Yapar” yazısı yer almaktadır (Resim 6) (Dortmund-postkolonial, 2017e).

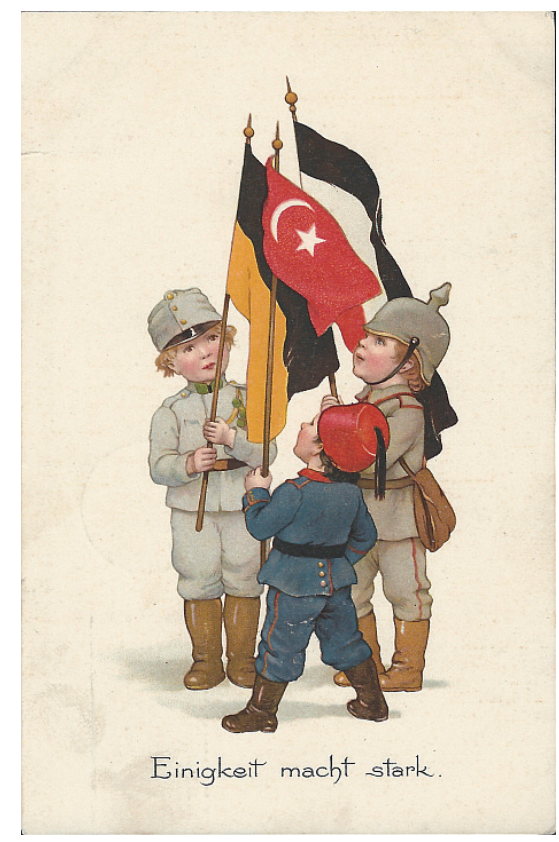

Resim 6: "Bayrak Taşıyan Çocuklar" Kartpostalı

Bu kartpostalda da Birinci Dünya Savaşı'nın dört İttifak Devleti'nden üçü (Türkiye, Almanya ve Avusturya-Macaristan) askeri üniforma ve bayrak metonimleri ile temsil edilmektedir. Alman propaganda kartpostalındaki karikatür Barthes'ın yananlam boyutunda değerlendirildiğinde, Almanya ve Avusturya-Macaristan'ı temsil eden iki çocuğun, Türkiye'yi temsil eden çocuktan daha büyük oldukları görülmektedir. Burada Türkiye'nin diğer iki ülkeye göre daha güçsüz ve zayıf bir ülke olduğu mesajı verilmektedir. Diğer yandan yananlam içerisinde savaşın Almanya ve AvusturyaMacaristan İmparatorluğu liderliğinde yapıldığı mesajı aktarılmaktadır. Kartpostalda savaşın kazanılması birliğin devamına bağlı olduğu ve birlikten daha güçlü olunacağı mitleri ortaya atılmaktadır. Nitekim kartpostalın hemen altında yer alan "Birlik Güçlü Yapar" yazısı oluşturulmak istenen bu miti destekler niteliktedir. Burada Türklere yönelik "müttefik" ve "dost" metaforları kullanıldığı görülmektedir. 


\section{Sonuc}

Kartpostallar, üzerinde resim bulunan zarflı veya zarfsız olarak kullanılan posta kartlarıdır. Bu kartların üzerinde siyaseten, spora, sanattan bilime kadar pek çok farklı konuda karikatürler bulunabilmektedir. 20. yüzyılda kartpostalların üzerindeki karikatürler tanıtımdan, reklama kadar pek çok farklı amaca hizmet etmiştir. Özellikle kartpostallar üzerinde bulunan bu karikatürler, Birinci Dünya Savaşı'nda yoğun olarak propaganda faaliyetlerinde kullanılmıştır. Bu çalışmada kapsamında incelenen Birinci Dünya Savaşı dönemindeki Alman propaganda kartpostallarındaki karikatürlerde, Alman İmparatorluğu'nun (2. Reich) müttefiki Türkiye'yi nasıl ve ne şekilde sunduğu ünlü Fransız Dilbilimci Roland Barthes'ın göstergebilimsel analiz metoduna göre yorumlanmıştır.

Almanlar, propaganda kartpostallarındaki karikatürlerde, müttefiki Türkleri genel olarak çocuk ve kadın asker şeklinde tasvir etmiştir. Kartpostallarda küçük çocuklara ve kadınlara sürekli olarak yer verilerek, savaşın sert ve acımasız yüzünün bir az olsun azaltılmaya çalışılığı görülmüştür. Diğer yandan, kadın ve çocukların karikatürlerde yer alması yananlam boyutundaki gizli mesajların verilmesini sağlamıştır. Türk toplumunu temsilen kullanılan kadın ve çocuk karikatürleri ile abartı ve mizah öğelerinin kullanılmasının da önü açıımıştır. Diğer yandan, karikatürlerde Türk köylüsünün günlük hayatına da yer verilerek, Türklerin doğal mekanları üzerinden propagandif mesajların oluşturulmaya çalışıldığı görüşmüştür.

Propaganda amaçlı kullanılan kartpostallardaki karikatürlerde Türkler genel olarak "misafirperver", "müttefik" ve "sadık dost" gibi olumlu metaforlar içinde gösterilmektedir. Karikatürlerde her ne kadar Türklere yönelik doğrudan olumsuz bir metafor kullanılmamışsa da, diğerlerine göre daha küçük olarak resmedilen çocuklar, Türklerin «güçsüz» ve «zayıf» metaforları içerisinde algılanmasına yol açmaktadır. Oluşturulan algılar çerçevesinde Alman propaganda karikatürlerinde; Türklerin, Almanya'nın yanında savaşa katılma arzusu içinde olduğu vurgulanmış, Türklerin Almanya ve Avusturya-Macaristan İmparatorluğu'na göre daha güçsüz ve zayıf bir ülke olduğundan Almanya'nın yardımına intiyaç duyduğu ifade edilmeye çalışıımıştır.

İncelenen karikatürlerde yer alan Türklerin doğrudan bir açıklama veya bir yazıyla Türk oldukları vurgulanmamıştır. Karikatürlerde Türk algısı, «şalvar», «bayrak» ve özellikle «fes» metonimleri içinde yer bulmuştur. Genel manada bakıldığında Alman karikatürlerinde Türklerin ağırlıklı olarak «fes» metonimi içinde sunulduğu ortaya çıkmıştır. Enver Paşa'nın Harbiye Nazırı (Savaş Bakanı) olması ile birlikte, Osmanlı askeri üniformaları değişmiş, fesin yerine askerler daha çok kalpak giymeye başlamıştır. Osmanlı askerleri fesi Birinci Dünya Savaşı'nda askeri üniformalarıyla birlikte kullanmamasına karşın Almanlar, eskiden beri algılarına yer eden fesi, Türkleri tanımlarken metonim olarak kullanmaya devam etmiştir. Bu bulgulardan, Alman karikatüristlerin tanıtmaya çalıştıkları Türk askerlerindeki değişimi yeterince kavrayamadıkları ve Almanların Türklerle ilgili var olan "her Türk fes giyer" stereotipinin hala geçerli olduğu sonuçlarına ulaşılabilinmektedir.

Alman propaganda kartpostallarındaki karikatürlerde, Türklere yönelik önemli birkaç mitin inşa edilmeye çalışıldığı gözlemlenmiştir. Bunlardan ilki, "Türklerin misafirperver olduğu ve müttefikleri Alman ve Avusturya-Macaristanlılara sıcak bir şekilde muamele 
ettikleri"'dir. Oluşturulmak istenen diğer bir mit, "Türklerin sadık ve güvenilir bir müttefik olduğu ve savaşın kazanılması için mutlak suretle Türk-Alman müttefikliğinin devam etmesi gerektiği'”'dir. Oluşturulan bu mitler ile Almanların Türkleri tanıması ve sevmesi amaçlanmıştır. Nitekim, Alman propaganda kartpostallarındaki karikatürlerde savaşın ilerleyen evresinde Almanya'nın Türkiye'ye yapmış olduğu yardımlarda Türklere yönelik olumlu bir algının oluşması sağlanmıştır. Buna karşın karikatürlerde inşa edilmeye çalışılan bir diğer mitin "Türklerin güçsüz bir ülke olduğu ve Osmanlı İmparatorluğu'nun Almanya ve Avusturya-Macaristan'ın yardımını istediği'”dir. Osmanlı Devleti'nin Birinci Dünya Savaşı'na girmeden önce Trablusgarp ve Birinci Balkan Savaşları'nda aldığı büyük yenilgiler Osmanlı'nın güçsüz olduğu mitinin oluşmasını desteklerken, Osmanlıların savaşın başında İtilaf Devletleri,nin yanında yer alma taleplerinin karşılıksız kalması üzerine yönlerini İttifak Devletleri,ne çevirmeleri de Türklerin İttifak Bloğu'na katılmayı arzuladığı mitini güçlendirmektedir.

Alman propaganda kartpostallarındaki yazıların yalnızca Almanca olduğu çalışma kapsamında gözlemlenmiştir. Bu açıdan kartpostalların yalnızca Alman İmparatorluğu ve Avusturya-Macaristan İmparatorluğu'nda yaşayan Almanlara yönelik yapıldığı sonucuna ulaşılmaktadır.

Genel manada Alman propaganda kartpostallarında Türklerin olumlu sunum kodları içerisinde yer buldukları gözlemlenmiştir. Nitekim çalışma kapsamında inşa edilmeye çalışılan mitler, Türklerin temsilinde kullanılan metaforlar, Barthes'ın yananlam boyutunda analiz edildiğinde Türklere yönelik olumlu bir algının oluşturulmaya çalışıldığı ortaya çıkmaktadır.

Karikatürlerde abartı ve mizah unsurları kullanılarak propaganda faaliyetlerinin kitleler üzerindeki etkisi arttırılabilmektedir. Nitekim, propaganda, propaganda yapanın elinde şekillenerek etkisini arttırabilen ikna odaklı bir iletişim türüdür. Bu açıdan kitlelerin etkilenmesi ve ikna edilmesi sürecinde karikatürler propagandaya önemli ölçüde katkı sağlar. Propagandacı, olumsuz yansıtmak istediği kişilerin olumsuz yönlerini abartarak daha da olumsuz, olumlu yansıtmak istediği kişilerin de olumlu yönlerini de abartarak daha da olumlu gösterir. Çalışmada kapsamında analiz edilen Alman propaganda kartpostallarındaki karikatürler de Birinci Dünya Savaşı'ndaki Alman algısının Türklere yönelik ne yönde olduğu ortaya konulmaya çalışmıştır. Sonuç olarak, Alman propaganda kartpostallarındaki karikatürlerin Türkleri, Alman kamuoyunda olumlu bir propaganda ile yansıttıkları tespit edilmiştir. Buna karşın çalışmanın sadece propaganda kartpostallarındaki karikatürler üzerinden sınırlı tutulması çalışmanın önemli bir sınırlılığını oluşturmaktadır. Bu açıdan gelecek çalışmalarda afiş, bildiri, gazete, dergi gibi farklı yazılı propaganda araçları üzerinden Birinci Dünya Savaşı'ndaki propaganda karikatürlerine ışık tutulması alana önemli katkı sağlayacaktır.

\section{Kaynakça}

Akarcalı, Sezer (2003). İkinci Dünya Savaşında İletişim ve Propaganda. Ankara: İmaj Yayınevi.

Aksakal, Mustafa (2011). "'Holy War Made in Germany'? Ottoman Origins of the 1914 Jihad”. War in History. 18(2). 184-199.

Alkan, Necmettin (2014). “Alman Kaynaklarına Göre Osmanlı Devleti'nin Birinci Dünya Savaşı'na Girmesi”. 1914'ten 2014'e 100'ncü Yılında Birinci Dünya Savaşı'nı Anlamak. (Ed.) Zekeriya Türkmen. ss.157- 179. İstanbul: Harp Akademileri Basımevi. 
Atabek, Necdet (2003). "Propaganda ve Toplumsal Kontrol”. Selçuk Üniversitesi Illetişim Fakültesi Akademik Dergisi. 2(4), 4-12.

Atar, Zafer (2015). "Il. Abdülhamid Döneminde Alman Eğitim Gemilerinin Osmanlı Sularındaki Seyahatleri" Journal of Modern Turkish History Studies/Çağdaş Türkiye Tarihi Araştırmaları Dergisi. 15(30).

Barthes, Roland (2016). Göstergebilimsel Serüven. Çev., Mehmet Rifat, Sema Rifat. 8.Baskı. İstanbul:Yapı Kredi Yayınları.

Barthes, Roland (2012). "The Eiffel Tower". AA Files, (64). 112-131.

Barthes, Roland (1980). S/Z: An Essay. Mexico:Siglo XXI.

Beşikçi, Mehmet (2012). The Ottoman Mobilization of Manpower in the First World War: Between Voluntarism and Resistance. Boston: Brill.

Beydilli, Kemal (1979). "2. Abdülhamîd Devrinde Gelen İlk Alman Askerî Heyeti Hakkında". Tarih Dergisi. (32). 481-494.

Brocks, Christine (2008). "Unser Schild Muss Rein Bleiben. Deutsche Bildzensur und-Propaganda im Ersten Weltkrieg". Militärgeschichtliche Zeitschrift. 67(1). 25-52.

Carlson, D. Jon (2009). "Postcards and Propaganda: Cartographic Postcards as Soft News Images of the Russo-Japanese War". Political Communication. 26(2). 212-237.

Chickering, Roger (2002). Das deutsche Reich und der Erste Weltkrieg. Deutschland: CH Beck.

Çakı, Caner, Zorlu, Yaşar, Karaca, Mustafa (2017). "Türk Sinemasında Nazizm İdeolojisi: "Kırımlı" Filmi ve Göstergebilimsel Analizi". Sosyoloji Konferansları - Istanbul Journal of Sociological Studies. No: 56. (2017-2). 65-93.

Çetin, Beyzade Nadir (2014). "Propaganda Olgusu ve Propagandanın Amerikanlaşması". Fırat Üniversitesi Sosyal Bilimler Dergisi. 24(2). 239-265.

Davies, Sarah Rosemary (1997). Popular Opinion in Stalin's Russia: Terror, Propaganda and Dissent, 1934-1941. United Kingdom: Cambridge University Press.

De Villalba, María Elena Del Valle (2013). "La Caricatura y su Uso Didáctico en el Estudio de la Primera Guerra Mundial”. Historia y Comunicación Social. 18. 75-85.

Demm, Eberhard (1993). "Propaganda and Caricature in the First World War". Journal of Contemporary History. 28(1). 163-192.

Diekmannshenke, Hajo (2006). "Polit-Postkarten: Propaganda, Wahlwerbung, politische Kommunikation". Girnth und Spieß. 97-120.

Domenach, Jean M. (2003). Politika ve Propaganda. Çev., Tahsin Yücel. İstanbul: Varlık Yayınları. "Dortmund Postkolonial." (2017a). http:// www. dortmund-postkolonial. de/? page_id =3372. 28.12.2017.

"Dortmund Postkolonial." (2017b). http:// www. dortmund-postkolonial. de/? attachment_id =5508. 28.12.2017.

"Dortmund Postkolonial." (2017c). http:// www. wwitoday. com/ wwiScLocation Detail.php?id =32. 30.12.2017.

"Dortmund Postkolonial." (2017d). "http://www.dortmund-postkolonial. de/? attachment_id= 3875. 30.12.2017.

"Dortmund Postkolonial." (2017e). http:// www. dortmund-postkolonial. de /?attachment_id= 3863. 28.12.2017.

Dupré, Ben (2013). "Propaganda. In 50 Schlüsselideen Politik". Springer Berlin Heidelberg. pp. 136-139. 
Elsig, Alexandre und Erismann, Peter (2014). "Im Feuer der Propaganda. Die Schweiz und der Erste Weltkrieg". Université de Fribourg, 8-46.

Fawcett, Bill (2011). Tarih Boyunca Yalan ve Propaganda, Çev., Nuray Önoğlu. İstanbul: Hitkitap. Fraser, John (1980). "Propaganda on The Picture Postcard". Oxford Art Journal. 3(2). 39-47.

Geray, Haluk (2014). İletişim Alanından Örneklerle Toplumsal Araştırmalarda Nicel ve Nitel Yöntemlere Giriş. Kocaeli: Umuttepe Yayınları.

Guhr, Hans (2007). Anadolu'dan Filistin'e Türklerle Omuz Omuza. Çev., Eşref Özbilen. İstanbul: Türkiye İş Bankası Yayınları.

Guiraud, Pierre (2016). Göstergebilim. Çev., Mehmet Yalçın. 3. Baskı. Ankara: İmge Kitabevi.

Harris, Ruth (1993). "'The Child of the Barbarian': Rape, Race and Nationalism in France during the First World War". Past \& Present. (141). 170-206.

Hoffmann, Heike (1997). "Schwarzer Peter im Weltkrieg: Die deutsche Spielwarenindustrie 1914-1918". NA. 323-335.

Howard, Michael (2003). The First World War. USA: Oxford University Press.

Işık, Mehmet ve Eşitti, Şakir (2015). "I. Dünya Savaşı Propaganda Afişlerinde Kadın Temsillerinin Toplumsal Cinsiyet Bağlamında Göstergebilimsel İncelenmesi”. Ankara Üniversitesi SBF Dergisi. Cilt: 70 Sayı: 3. 655-682.

Jaworski, Rudolf (2015). Mütter-Liebchen-Heroinen: Propagandapostkarten aus dem Ersten Weltkrieg. Österreich: Böhlau Verlag Köln Weimar.

Jebsen, Nina (2015). Als die Menschen gefragt wurden: eine Propagandaanalyse zu Volksabstimmungen in Europa nach dem Ersten Weltkrieg. Deutschland: Waxmann Verlag.

Jowett, Garth S ve O'donnell, Victoria (2014). Propaganda \& Persuasion. USA: Sixth Edition, Sage.

Keleş, Necdet (2016). "Birinci Dünya Savaşı Öncesi ve Sonrasında Almanlarda Türk İmgesi." Pamukkale University Journal of Social Sciences Institute/Pamukkale Üniversitesi Sosyal Bilimler Enstitüsü Dergisi. (24). 113-142.

Kent, Marian (2005). The Great Powers and The End of The Ottoman Empire. Great Britain: Routledge.

Krieg, Hans (1939). Landkarten als Mittel der Politischen Propaganda. "Zeitschrift für Politik." 29(11/12), 663-669.

Kalkan Kocabay, Hasibe (2008). Tiyatroda Göstergebilim. İstanbul: E Yayınları.

McMeekin, Sean (2011). The Russian Origins of The First World War. USA: Harvard University Press.

Messinger, Gary S. (1992). British Propaganda and The State in the First World War. Great Britain: Manchester University Press.

Mommsen, Wolfgang (1993). "Der Erste Weltkrieg und die Krise Europas. Gerhard Hirschfeld". Heinrich August Winkler: Mußte Weimar scheitern, ss 25-41.

Mulligan, William (2017). The Origins of the First World War. (Vol. 52). United Kingdom: Cambridge University Press.

Mühlman, Carl (2009). İmparatorluğun Sonu 1914, Osmanlı Savaşa Neden ve Nasıl Girdi?. Çev., Kadir Kon. İstanbul: Timaş Yayınları.

Lasswell, Harold Dwight (1927). "The Theory of Political Propaganda". The American Political Science Review. 21(3). 627-631. 
Ortaylı, İlber (2006). Osmanlı İmparatorluğu'nda Alman Nüfuzu. 9. Baskı. İstanbul: Alkım Yayınları. Öymen, Onur (2014). Bir Propaganda Silahı Olarak Basın. İstanbul: Remzi Kitabevi.

Özen, Mustafa (2008). "Visual Representation and Propaganda: Early Films and Postcards in The Ottoman Empire, 1895-1914". Early Popular Visual Culture. 6(2). 145-157.

Özgişi, Tunca (2013). "Bir Siyasi İmge Olarak Çocuk ve Savaşlar: I. Dünya Savaşı Örneği". Electronic Turkish Studies. 8(11). 293-312.

Qualter, H. Terence (1980). "Propaganda Teorisi ve Propagandanın Gelişimi”. Çev., Tunca Öskay. Ankara Üniversitesi SBF Dergisi. 35(01). 255-307.

Rıfat, Mehmet (2013). Açıklamalı Göstergebilim Sözlüğü: Kavramlar, Yöntemler, Kuramcılar, Okullar. İstanbul:Türkiye İş Bankası Kültür Yayınları.

Rother, Rainer und Breymayer, Ursula (1995). "Bilder des Ersten Weltkrieges. In Geschichte in Bildern". Centaurus Verlag \& Media. pp. 93-111.

Rudwick, Martin J. S. (1975)."Caricature as a Source for the History of Science: De la Beche's anti-Lyellian Sketches of 1831". Isis, 66(4). 534-560.

Salih, Kış (2017). "Alman İmparatoru II. Wilhelm'in Haçı Rüyası ve 1898 Kudüs Seyahati/The Crusader Dream of Wilhelm II The German Emperor and His Journey to Jerusalem". Selçuk Üniversitesi Türkiyat Araştırmaları Dergisi. 1(42). 487-506.

Saunders, Nicholas J (2004). Matters of Conflict: Material Culture, Memory and The First World War. Great Britain: Routledge.

Scholl, Lars U (1987). "Karl Bloßfeld als Marinemaler: eine Nachlese”. Deutsches Schiffahrtsarchiv. 10. 345-352.

Schwendinger, Christian (2010). Kriegspropaganda in der Habsburgermonarchie im Zuge des Ersten Weltkriegs: Eine Analyse anhand fünf ausgewählter Zeitungen. Hamburg: Diplom. de.

Sepetçi, Tülin (2016). "Levi-Strauss ve Roland Barthes'ın Yaklaşımıyla 'God of War III' Oyununun Mitsel Çözümlemesi». TRT Akademi. Cilt 01, Sayı 02. 488-507.

Sığırcı, İrfan (2016), Göstergebilim Uygulamaları, Metinleri, Görselleri ve Olayları Okuma. Ankara: Seçkin Yayıncılık.

"Sikh Museum." (2018). http://www. sikhmuseum.com/ brighton/doctor/ analysis/ enemy. 16.03.2018.

Strachan, Hew (2004). Der Erste Weltkrieg. Eine Neue illustrierte Geschichte. München: Bertelsmann.

Tanyeri Mazıcı, Emel ve Çakı, Caner (2018). "Adolf Hitler'in Korku Çekiciliği Bağlamında Kamu Spotu Reklamlarında Kullanımı”. Erciyes İletişim Dergisi. 5 (3). 290-306.

Tarhan, Nevzat (2010). Psikolojik Savaş, Gri Propaganda. İstanbul: Timaş Yayınları.

Taylor, Richard (1998). Film Propaganda: Soviet Russia and Nazi Germany. India: IB Tauris.

Tutsak, Sadiye (2014). "Türk İstiklâl Harbi'nde Alman Silahları ve Askerî Mühimmatı". Ankara Üniversitesi Osmanlı Tarihi Araştırma ve Uygulama Merkezi Dergisi. 36 /Güz. 229-260.

Ünal, Mehmet Fatih (2016). "Göstergebilimin Serüveni”. Mütefekkir. 3(6). 379-398.

Von Sanders, Liman (2006) Türkiye'de Beş Yıl. Çev., Resul Bozyel. İstanbul: Kesit Yayınları.

Weiss, Peter ve Stehle, Karl (1988). "Die Postkarte in den Zwanziger Jahren. In Reklamepostkarten". Birkhäuser Basel. pp. 79-94.

Welch, David (2002). The Third Reich: Politics and Propaganda. London: Psychology Press.

Wilke, Jürgen (2007). Presseanweisungen im Zwanzigsten Jahrhundert: Erster Weltkrieg, Drittes Reich, DDR. Deutschland: Böhlau Verlag Köln Weimar. 